\title{
Rubiaceae-type cyclopeptides from Galianthe thalictroides
}

Patrícia de Oliveira Figueiredo, $* \dagger$ Renata Trentin Perdomo, $\uparrow$ Wilson Hino Kato Junior, $\dagger$ Marcos Vinícius Gonçalves de Oliveira Barros, † Maria de Fatima Cepa Matosł, Fernanda Rodrigues Garcez, $\dagger$ Walmir Silva Garcez $\dagger$

† Instituto de Química, Universidade Federal de Mato Grosso do Sul, Campo Grande, MS 79074-460, Brazil

† Centro de Ciências Biológicas e da Saúde, Universidade Federal de Mato Grosso do Sul, Campo Grande, MS 79070-900, Brazil

* E-mail: patricia.figueiredo@ufms.br Tel. +55-67-3345-3599

Fax: $+55-67-3345-3552$ 
Table S 1- ${ }^{1} \mathrm{H}$ and ${ }^{13} \mathrm{C}$ NMR data from 6-O-methylbouvardin (1) in $\mathrm{CDCl}_{3}$. $^{\text {a }}$

\begin{tabular}{|c|c|c|}
\hline \multicolumn{3}{|c|}{$\begin{array}{c}\text { Compound } 1 \\
\text { (6- } O \text {-methylbouvardin) }\end{array}$} \\
\hline & Type, $\delta^{13} \mathrm{C}$ & $\delta^{1} \mathrm{H}(J$ in $\mathrm{Hz})$ \\
\hline \multicolumn{3}{|l|}{$D-A l a^{l}$} \\
\hline$\alpha$ & $\mathrm{CH}, 47.8$ & $4.37, \mathrm{~m}$ \\
\hline$\beta$ & $\mathrm{CH}_{3}, 20.5$ & $1.30, \mathrm{~d}(6.8)$ \\
\hline $\mathrm{C}=\mathrm{O}$ & $\mathrm{C}, 172.1$ & - \\
\hline \multicolumn{3}{|l|}{$L-A l a^{2}$} \\
\hline$\alpha$ & $\mathrm{CH}, 44.8$ & $4.75, \mathrm{~m}$ \\
\hline$\beta$ & $\mathrm{CH}_{3}, 16.3$ & $1.26, \mathrm{~d}(7.1)$ \\
\hline $\mathrm{C}=\mathrm{O}$ & C, 172.5 & - \\
\hline \multicolumn{3}{|l|}{$L-T y r^{3}$} \\
\hline$\alpha$ & $\mathrm{CH}, 68.1$ & 3.64, dd $(9.9,5.6)$ \\
\hline$\beta$ & $\mathrm{CH}_{2}, 32.6$ & $3.36, \mathrm{~m}$ \\
\hline$\gamma$ & C, 130.6 & - \\
\hline$\dot{\delta}$ & $\mathrm{CH}, 130.2$ & $7.02, \mathrm{~d}(8.5)$ \\
\hline$\xi$ & $\mathrm{CH}, 114.0$ & $6.80, \mathrm{~d}(8.5)$ \\
\hline$\zeta$ & $\mathrm{C}, 158.4$ & - \\
\hline $\mathrm{N}-\mathrm{Me}$ & $\mathrm{CH}_{3}, 39.7$ & $2.90, \mathrm{~s}$ \\
\hline $\mathrm{O}-\mathrm{Me}$ & $\mathrm{CH}_{3}, 55.2$ & $3.81, \mathrm{~s}$ \\
\hline $\mathrm{C}=\mathrm{O}$ & $\mathrm{C}, 168.2$ & - \\
\hline \multicolumn{3}{|l|}{$L-A l a^{4}$} \\
\hline$\alpha$ & $\mathrm{CH}, 46.4$ & $4.88, \mathrm{~m}$ \\
\hline$\beta$ & $\mathrm{CH}_{3}, 18.5$ & $1.08, \mathrm{~d}(6.6)$ \\
\hline $\mathrm{C}=\mathrm{O}$ & $\mathrm{C}, 172.1$ & - \\
\hline \multicolumn{3}{|l|}{$L-T y r^{5}$} \\
\hline$\alpha$ & $\mathrm{CH}, 53.8$ & 5.36, bs \\
\hline$\beta$ & $\mathrm{CH}, 78.4$ & $5.07, \mathrm{bs}$ \\
\hline$\gamma$ & $\mathrm{C}, 139.3$ & - \\
\hline$\delta a$ & $\mathrm{CH}, 126.8$ & 7.39, dd $(8.5,1.9)$ \\
\hline$\delta \mathrm{b}$ & $\mathrm{CH}, 128.2$ & 7.49, dd $(8.5,2.2)$ \\
\hline$\xi \mathrm{a}$ & $\mathrm{CH}, 125.7$ & 7.26, dd $(8.5 ; 1.9)$ \\
\hline$\xi \mathrm{b}$ & $\mathrm{CH}, 124.2$ & 7.00, dd $(8.5,2.2)$ \\
\hline$\zeta$ & $\mathrm{C}, 158.9$ & - \\
\hline $\mathrm{N}-\mathrm{Me}$ & $\mathrm{CH}_{3}, 33.0$ & $3.31, \mathrm{~s}$ \\
\hline $\mathrm{C}=\mathrm{O}$ & $\mathrm{C}, 170.8$ & - \\
\hline \multicolumn{3}{|l|}{$L-T y r^{6}$} \\
\hline$\alpha$ & $\mathrm{CH}, 57.6$ & 4.36 , dd $(11.8,3.4)$ \\
\hline$\beta$ & $\mathrm{CH}_{2}, 35.7$ & 2.93, dd $(17.6,3.4)$ \\
\hline$\gamma$ & $\mathrm{C}, 127.6$ & - \\
\hline$\delta \mathrm{a}$ & $\mathrm{CH}, 121.0$ & 6.61, bd (7.9) \\
\hline$\delta \mathrm{b}$ & $\mathrm{CH}, 113.1$ & 4,40, bs \\
\hline$\xi \mathrm{a}$ & $\mathrm{CH}, 112.4$ & $6.77, \mathrm{~d}(8.4)$ \\
\hline$\xi \mathrm{b}$ & $\mathrm{C}, 152.9$ & - \\
\hline$\zeta$ & C, 146.7 & - \\
\hline $\mathrm{N}-\mathrm{Me}$ & $\mathrm{CH}_{3}, 29.2$ & $2.70, \mathrm{~s}$ \\
\hline $\mathrm{O}-\mathrm{Me}$ & $\mathrm{CH}_{3}, 56.1$ & $3.95, \mathrm{~s}$ \\
\hline $\mathrm{C}=\mathrm{O}$ & $\mathrm{C}, 170.0$ & - \\
\hline
\end{tabular}

${ }^{a}$ Recorded at 300/75 MHz. Chemical shifts referenced to residual $\mathrm{CHCl}_{3} \cdot{ }^{\mathrm{b}} \mathrm{H} \rightarrow \mathrm{C}$. 
$H R-E S I-M S / M S$ analysis of $\mathbf{1}$ and 2 . The structures of $\mathbf{1}$ and $\mathbf{2}$ were also confirmed by the evidence of peptide fragments in their HRESIMS/MS spectra (Fig. S 1 and Fig. S 2). According to Paizs and Suhai, ${ }^{1}$ cyclic peptide fragmentations are dominated by the $b_{x}-y_{z}$ pathway, in which ring opening takes place via oxazolone formation, resulting in a linear peptide ion having a free $\mathrm{N}$-terminus and an oxazolone ring at the $\mathrm{C}$-terminus (Fig. S 2A). This linear ion can originate a lower $b$ fragment via the $b_{x} \rightarrow b_{x-1}$ pathway, which in turn loses $\mathrm{CO}$ via the $\mathrm{b}_{\mathrm{x}} \rightarrow \mathrm{a}_{\mathrm{x}}$ pathway, among other possible fragmentations and common neutral losses. ${ }^{1,2}$
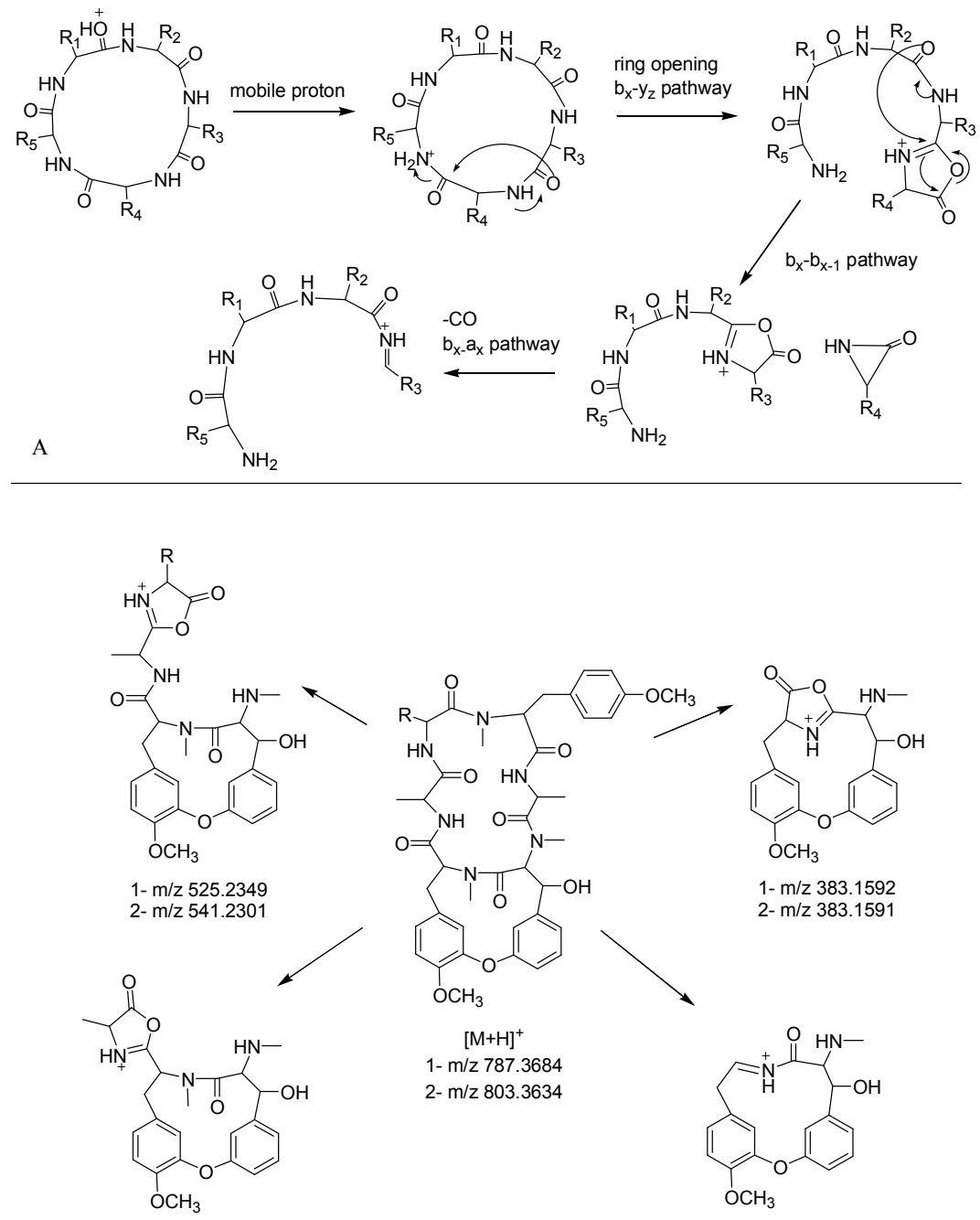

$1-\mathrm{m} / \mathrm{z} 454.1966$
B $\quad 2-\mathrm{m} / \mathrm{z} 454.1978$
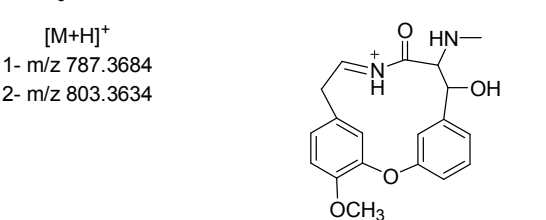
1- $\mathrm{m} / \mathrm{z} 787.3684$ 2- $\mathrm{m} / \mathrm{z} 803.3634$

$1-\mathrm{m} / \mathrm{z} 355.1640$ 2- $\mathrm{m} / \mathrm{z} 355.1640$

Fig. S 1 - A: General fragmentation pathways of cyclopeptides. B: Proposed fragments for 6-Omethylbouvardin (1) and 5 $\beta$-hydroxy-RA-III (2), based on HRESIMS/MS analysis. 
MS/MS spectra of linear peptides and cyclopeptides usually show fragment ions formed via a macrocyclic intermediate that undergoes further fragmentation following ring opening at various positions, resulting in non-sequence product ions via rearrangement (Fig. S 3). ${ }^{2-4}$ Some ions in the MS/MS spectrum of 5 5 - hydroxy-RA-III may have been formed via this fragmentation pathway, as shown in Fig. S 3 for the ion at $m / z 470.1916$. 


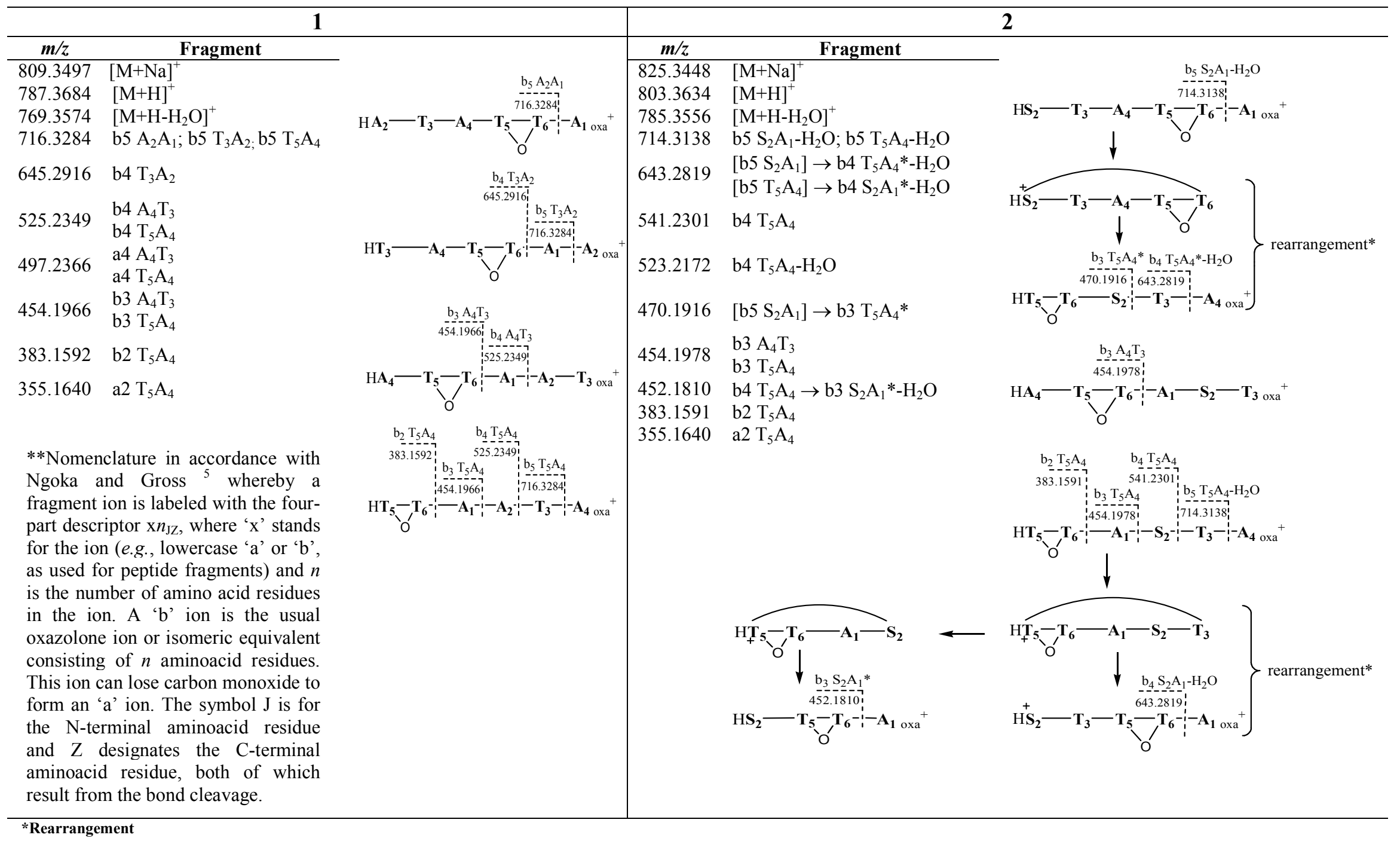

Fig. S 2 - Main fragment ions in the HR-ESI-MS/MS spectra of 6-O-methylbouvardin (1) and 5ß-hydroxy-RA-III (2). 

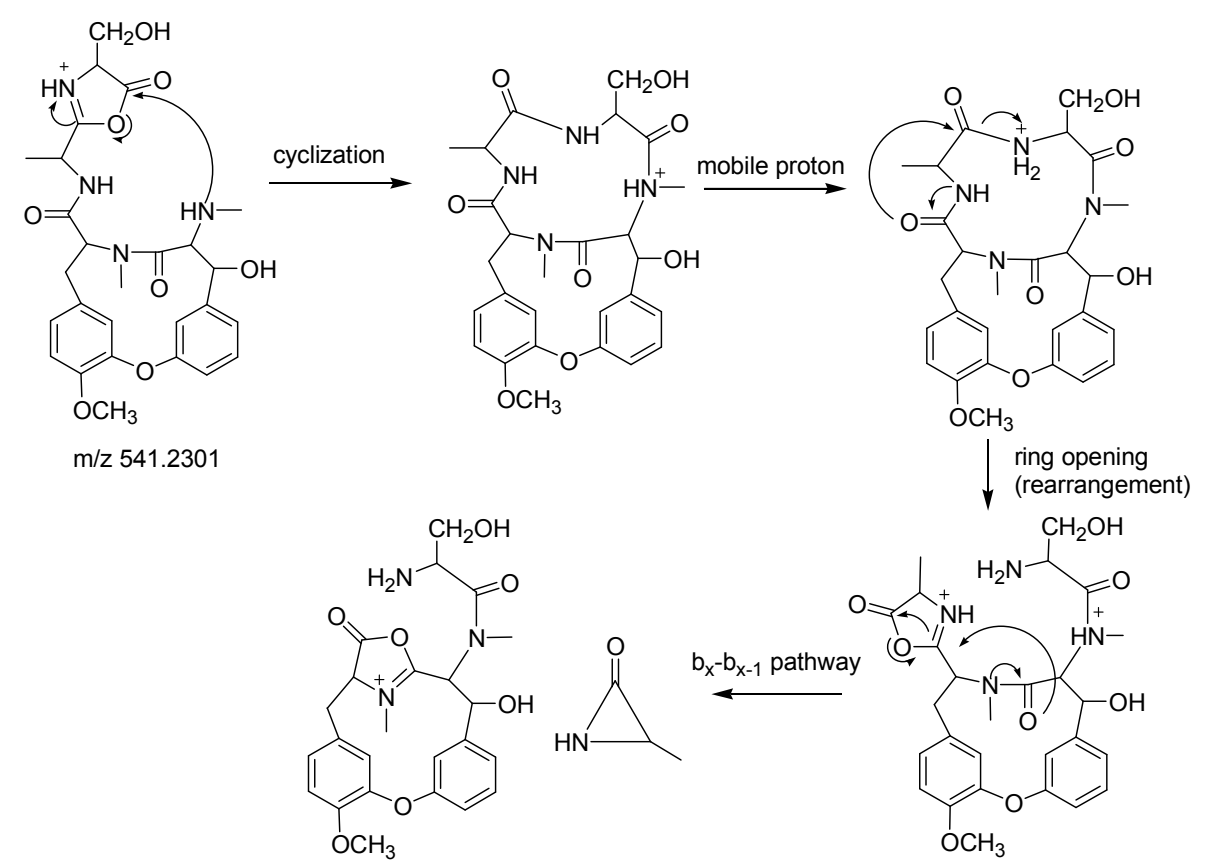

$\mathrm{m} / \mathrm{z} 470.1916$

Fig. S 3- Proposed fragmentations which yielded the ion $m / z 470.1916$ in the MS/MS spectrum of $5 \beta$-hydroxy-RA-III via peptide rearrangement.

\section{Marfey's analysis of absolute configuration of amino acids ${ }^{6,7}$}

In separate experiments, compounds 1 and 2 were hydrolyzed by adding $1 \mathrm{~mL}$ of $6 \mathrm{~N}$ $\mathrm{HCl}$ at $95{ }^{\circ} \mathrm{C}$ for $16 \mathrm{~h}$. The hydrolysates were evaporated to dryness under a stream of $\mathrm{N}_{2}$ to remove traces of $\mathrm{HCl}$. The hydrolysates were redissolved in $900 \mu \mathrm{L}$ of acetone and $1 \mathrm{M} \mathrm{NaHCO} 3(20 \mu \mathrm{L})$ and $1 \%$ solution of $\mathrm{N}-\alpha$-(2,4-dinitro-5-fluorophenyl)-Lalaninamide (L-FDAA, Marfey's reagent, Sigma, $100 \mu \mathrm{L}$ ) was added. The mixtures were heated at $40{ }^{\circ} \mathrm{C}$ for $1 \mathrm{~h}$. The reaction mixtures were cooled to room temperature, quenched by addition of $2 \mathrm{~N} \mathrm{HCl}(10 \mu \mathrm{L})$, dried, and dissolved in $50 \%$ aqueous $\mathrm{CH}_{3} \mathrm{CN}$ $(600 \mu \mathrm{L})$. Five microliters of the FDAA derivative were subjected to HPLC, using a $\mathrm{RP} 18$ column at room temperature $\left(20^{\circ} \mathrm{C}\right)$. Aqueous $\mathrm{CH}_{3} \mathrm{CN}$ containing $4 \%$ TFA was used as the mobile phase, with linear gradient elution $(20-35 \%, 40 \mathrm{~min})$ for L-and Dserine retention time analysis and with isocratic elution $(45 \% \mathrm{ACN})$ for L-and D- 
alanine retention time analysis at a flow rate of $1 \mathrm{~mL} / \mathrm{min}$. FDAA-derived amino acids were detected by absorption at $340 \mathrm{~nm}$.

Aliquots of both $1 \mathrm{M} \mathrm{NaHCO}_{3}(20 \mu \mathrm{L})$ and a $1 \%$ solution of L-FDAA in acetone $(100 \mu \mathrm{L})$ were added to four separate $50 \mu \mathrm{L}$ volumes of $50 \mathrm{mM}$ aqueous solutions of either D or L configurations of either Ala or Ser. The mixtures were heated at $40{ }^{\circ} \mathrm{C}$ for $1 \mathrm{~h}$. Each reaction mixture was cooled to room temperature, quenched by addition of 2 $\mathrm{N} \mathrm{HCl}(10 \mu \mathrm{L})$, dried, and further dissolved in $50 \%$ aqueous $\mathrm{CH}_{3} \mathrm{CN}(600 \mu \mathrm{L})$. A $5 \mu \mathrm{L}$ aliquot of each FDAA derivative was separately analyzed by HPLC. The retention times (min) of each L-FDAA derivative of standard amino acid and residual Marfey's reagent were as follows: 7.54 (L-Ala) and 9.43; 8.39 (D-Ala) and 9.38; 8.85 (L-Ser) and 16.04; and 9.22 (D-Ser) and 15.91, respectively. The retention times (min) of each L-FDAA derivative of acid hydrolysate of $\mathbf{1}$ were as follows: 7.88 (L-Ala) and 9.75; and 8.45 (DAla) and 9.75, respectively. For compound 2, these times were 7.87 (L-Ala) and 9.69; 8.43 (D-Ala) and 9.69; and 8.74 (L-Ser) and 15.89, respectively.

\section{In vitro cytotoxicity assay}

The cytotoxicities of $\mathbf{1}$ and $\mathbf{2}$, as well as of the respective final fractions from which they were isolated, were measured in vitro according to growth inhibition of 786-0 (ATCCCRL-1932, human kidney carcinoma), PC-3 (ATCC-CRL-1435, human prostate carcinoma), and HT-29 (ATCC-HTB-38, human colon carcinoma) cell lines provided by Prof. João Ernesto de Carvalho (Centro Pluridisciplinar de Pesquisas Químicas Biológicas e Agrícolas, Universidade Estadual de Campinas, Brazil). To this end, a sulforhodamine B (SRB; purity $\geq 97 \%$; Sigma) assay was performed as described elsewhere. ${ }^{8,9}$ Doxorubicin hydrochloride ( $2 \mathrm{mg} / \mathrm{mL}$, Libbs) was used as the positive control. Each sample was tested in triplicate at four concentrations $(0.25,2.5,25$, and 
$250 \mu \mathrm{g} / \mathrm{mL}$ ) or, when it was necessary, at concentrations of $0.025,0.25,2.5$ and 25 $\mu \mathrm{g} / \mathrm{mL}$ ), for ten times. $\mathrm{IC}_{50}$ was determined through nonlinear regression analysis using Origin 6.0 software (OriginLab). 


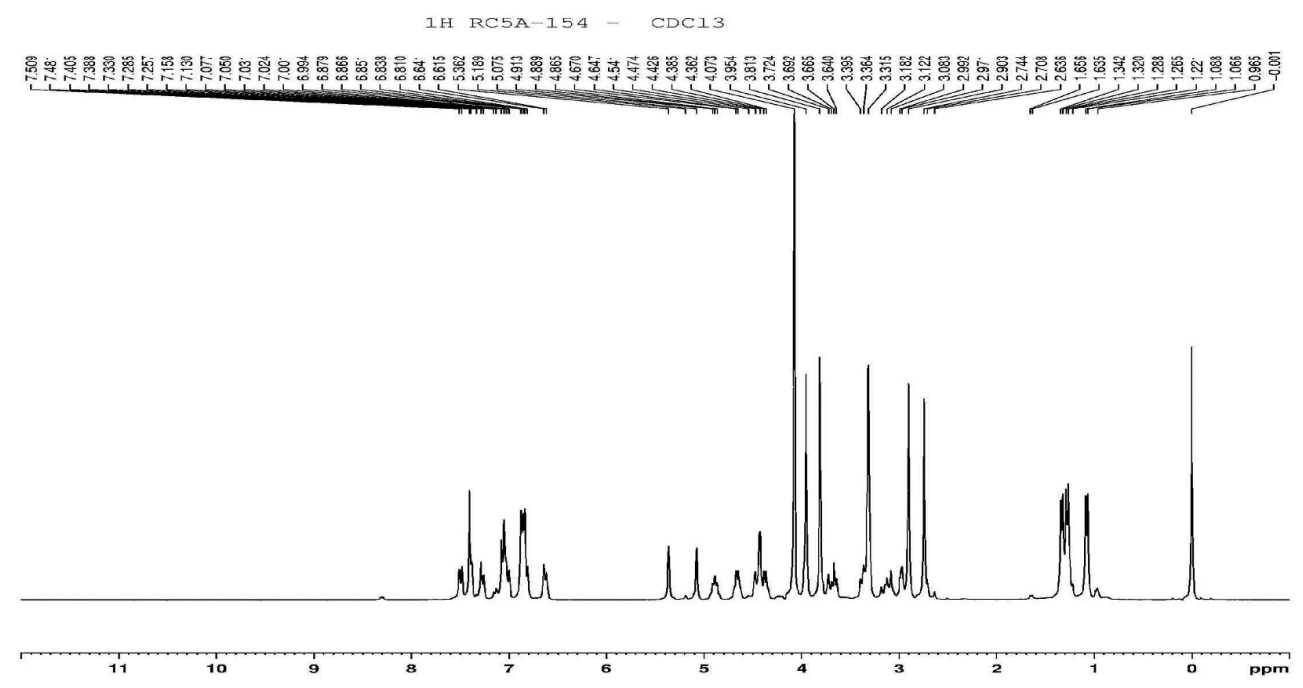

Fig. S 4- ${ }^{1} \mathrm{H}$ NMR (300 MHz, $\mathrm{CDCl}_{3}$ ) spectrum of 6-O-methylbouvardin.
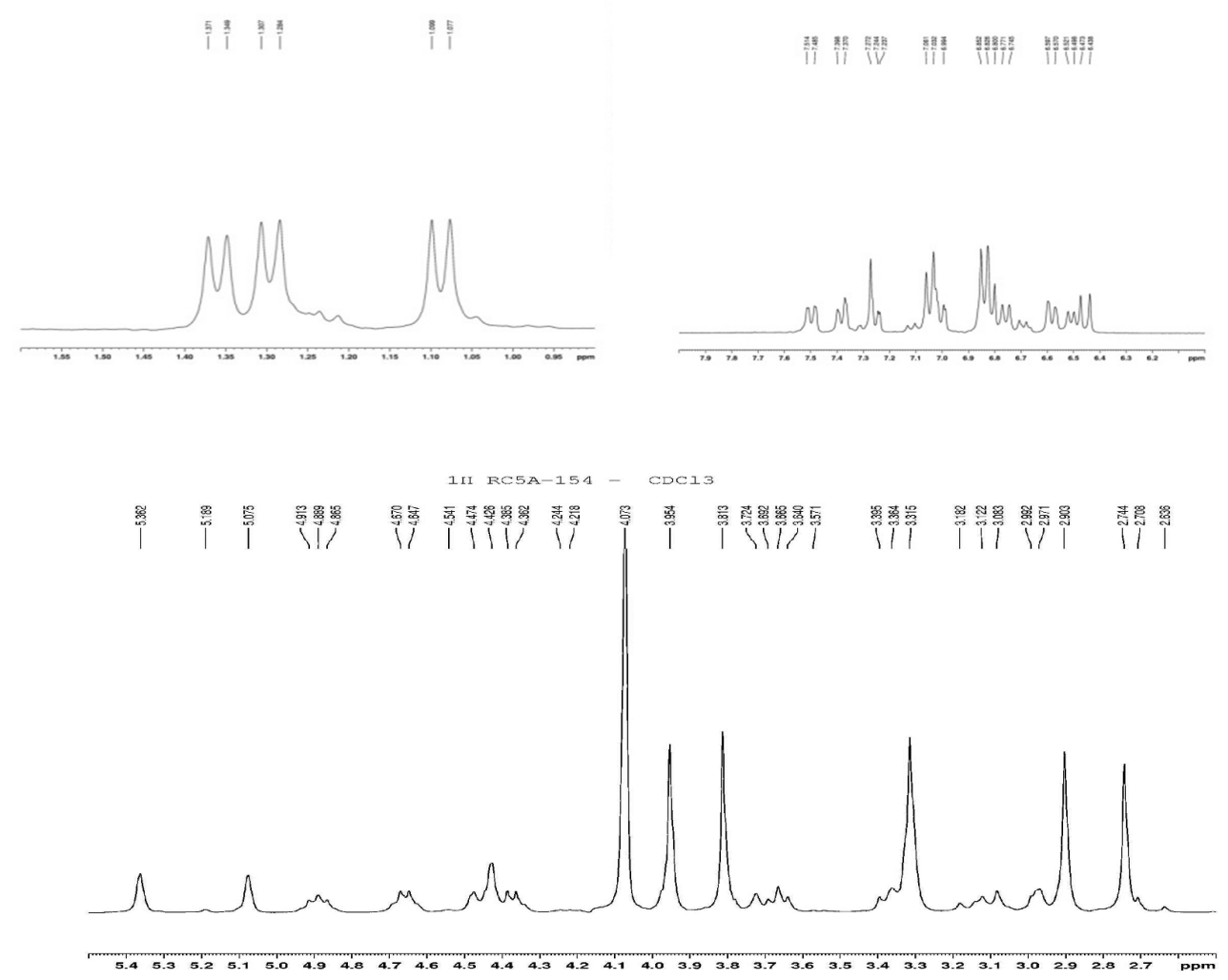

Fig. S 5- ${ }^{1} \mathrm{H}$ NMR (300 $\mathrm{MHz}, \mathrm{CDCl}_{3}$ ) spectrum expansion of 6-O-methylbouvardin. 
$13 C-R C 5 A-154-$ CDC13

A
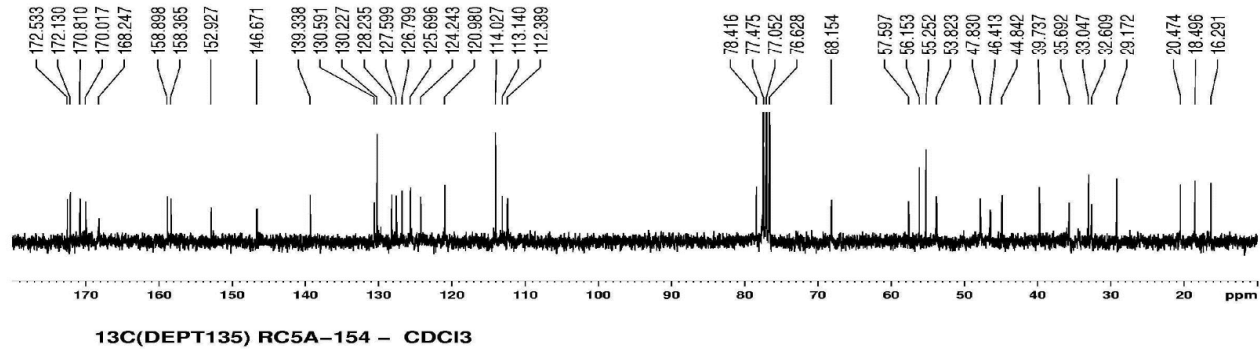

B
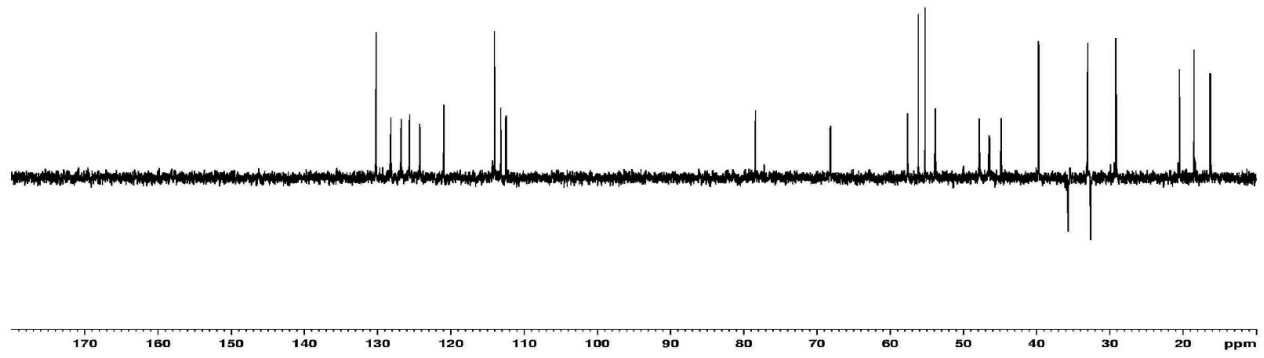

Fig. S 6 - A: ${ }^{13} \mathrm{C}$ NMR (75 MHz, $\mathrm{CDCl}_{3}$ ) spectrum of 6-O-methylbouvardin. B: DEPT $135^{\circ}$ NMR (75 $\mathrm{MHz}, \mathrm{CDCl}_{3}$ ) spectrum of 6-O-methylbouvardin.

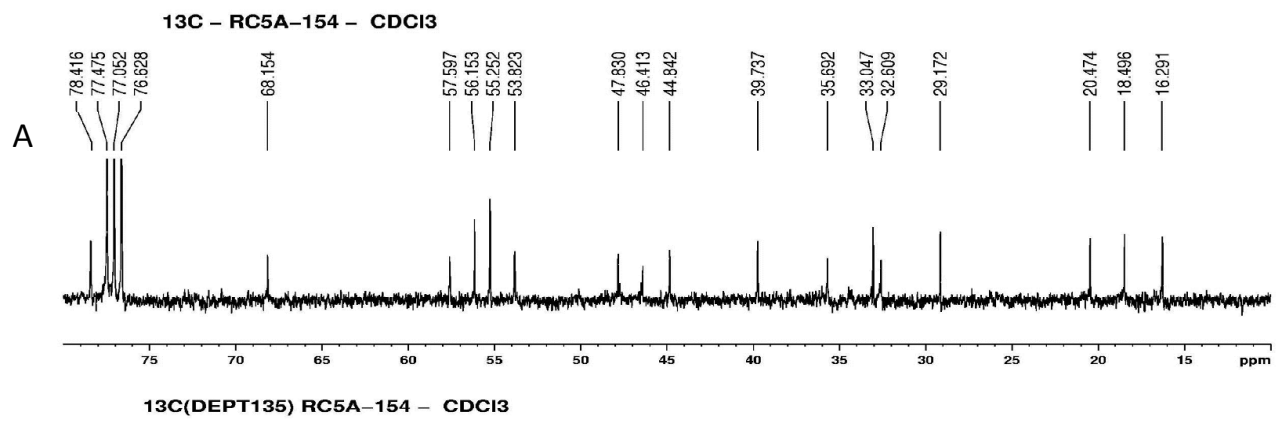

B
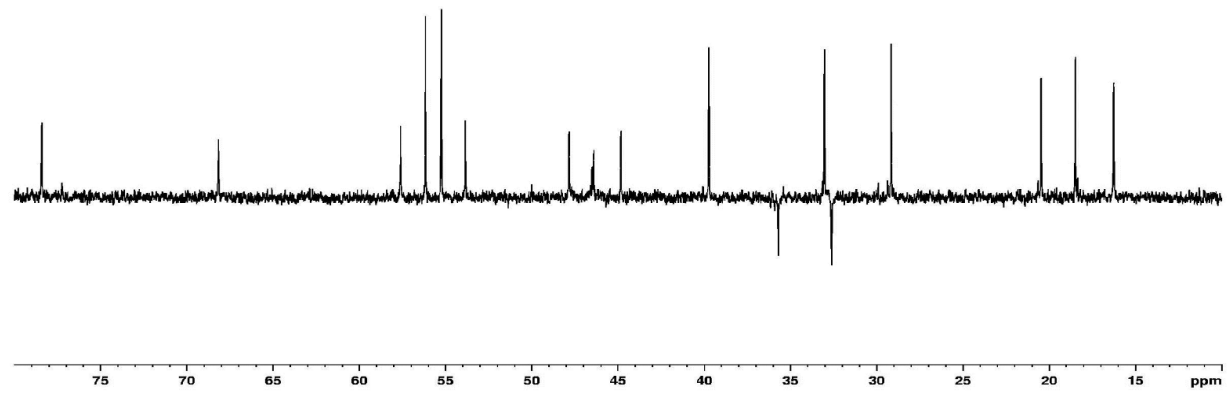

Fig. S 7 - A: ${ }^{13} \mathrm{C}$ NMR (75 $\mathrm{MHz}, \mathrm{CDCl}_{3}$ ) spectrum expansion of 6-O-methylbouvardin. B: DEPT 135 NMR (75 MHz, $\mathrm{CDCl}_{3}$ ) spectrum expansion of 6-O-methylbouvardin. 
A $13 \mathrm{C}-\mathrm{RC} 5 \mathrm{~A}-154-\mathrm{CDCl} 3$
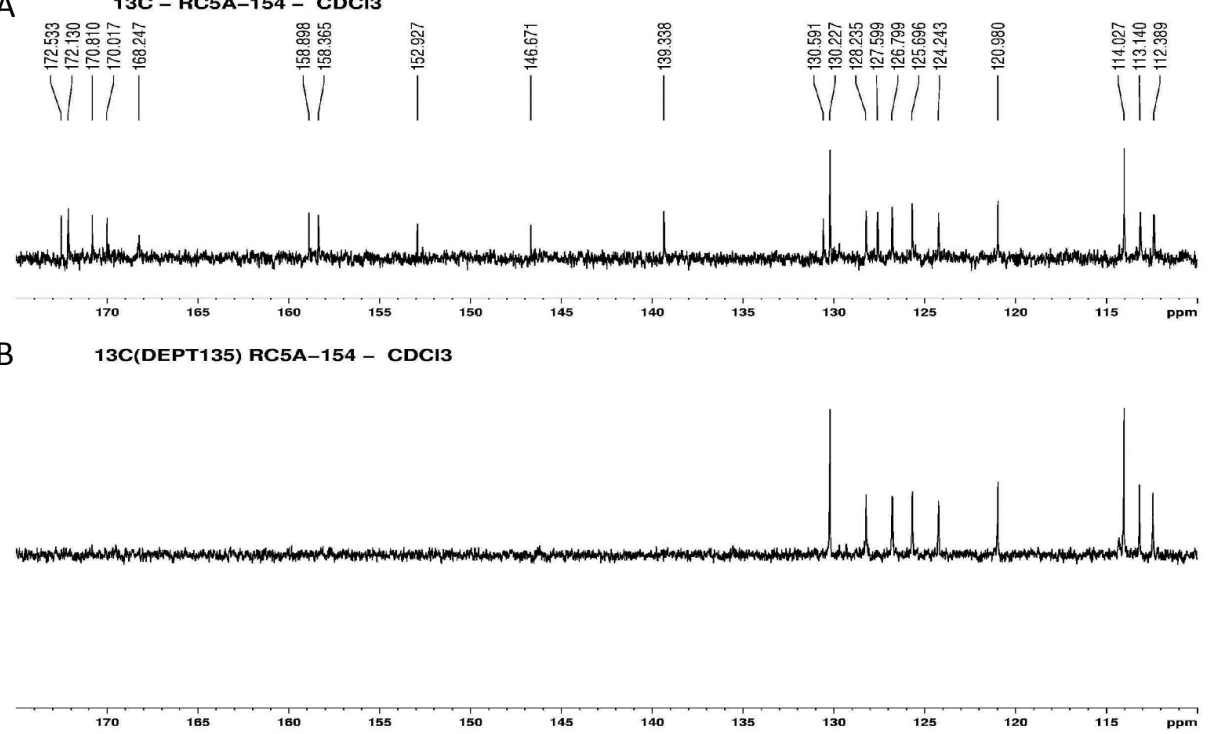

Fig. S 8 - A: ${ }^{13} \mathrm{C}$ NMR (75 MHz, $\mathrm{CDCl}_{3}$ ) spectrum expansion of 6-O-methylbouvardin. B: DEPT $135 \mathrm{NMR}\left(75 \mathrm{MHz}, \mathrm{CDCl}_{3}\right.$ ) spectrum expansion of 6-O-methylbouvardin.

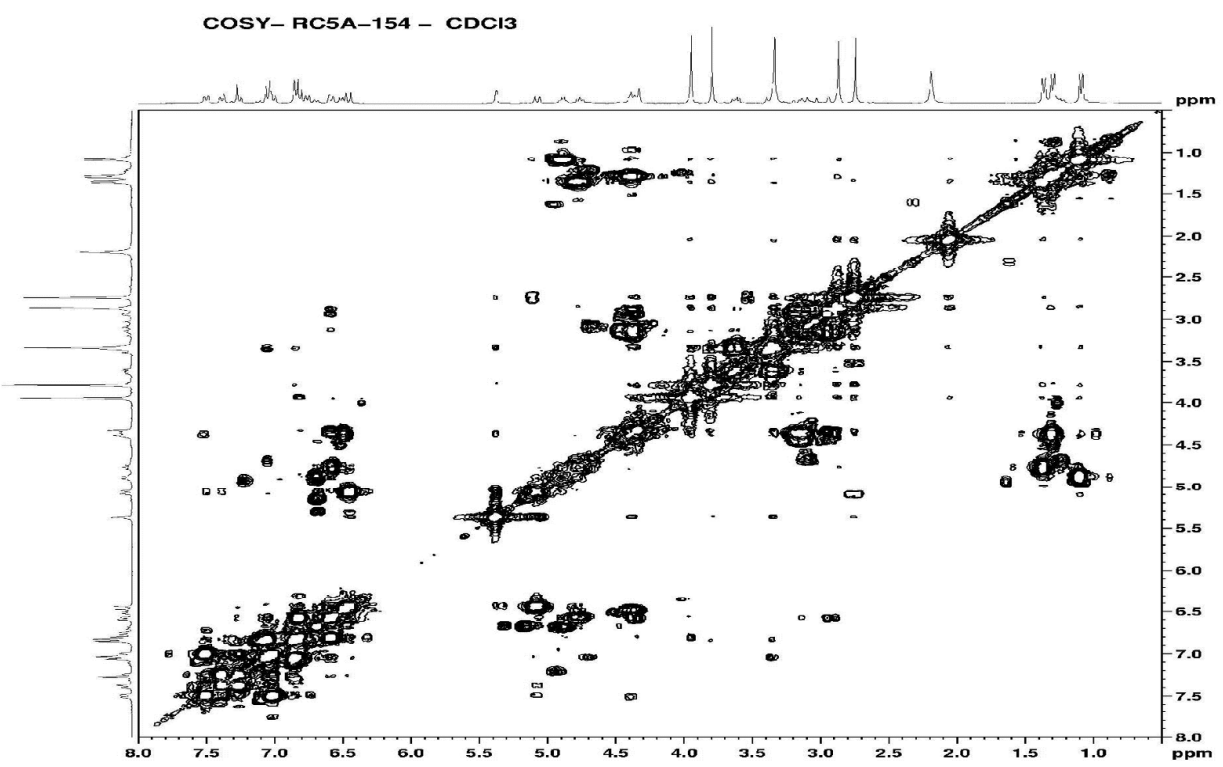

Fig. S 9 - COSY NMR (300 $\left.\mathrm{MHz}, \mathrm{CDCl}_{3}\right)$ spectrum of 6-O-methylbouvardin. 


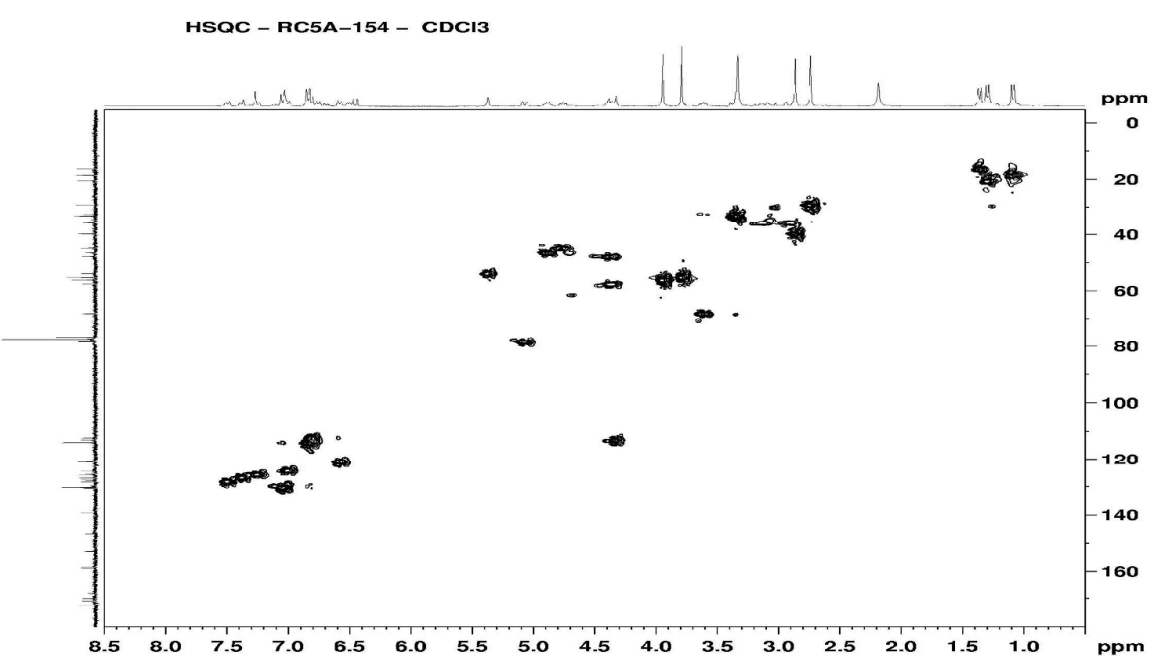

Fig. S 1 - HSQC NMR (300/75 $\mathrm{MHz}, \mathrm{CDCl}_{3}$ ) spectrum of 6-O-methylbouvardin.
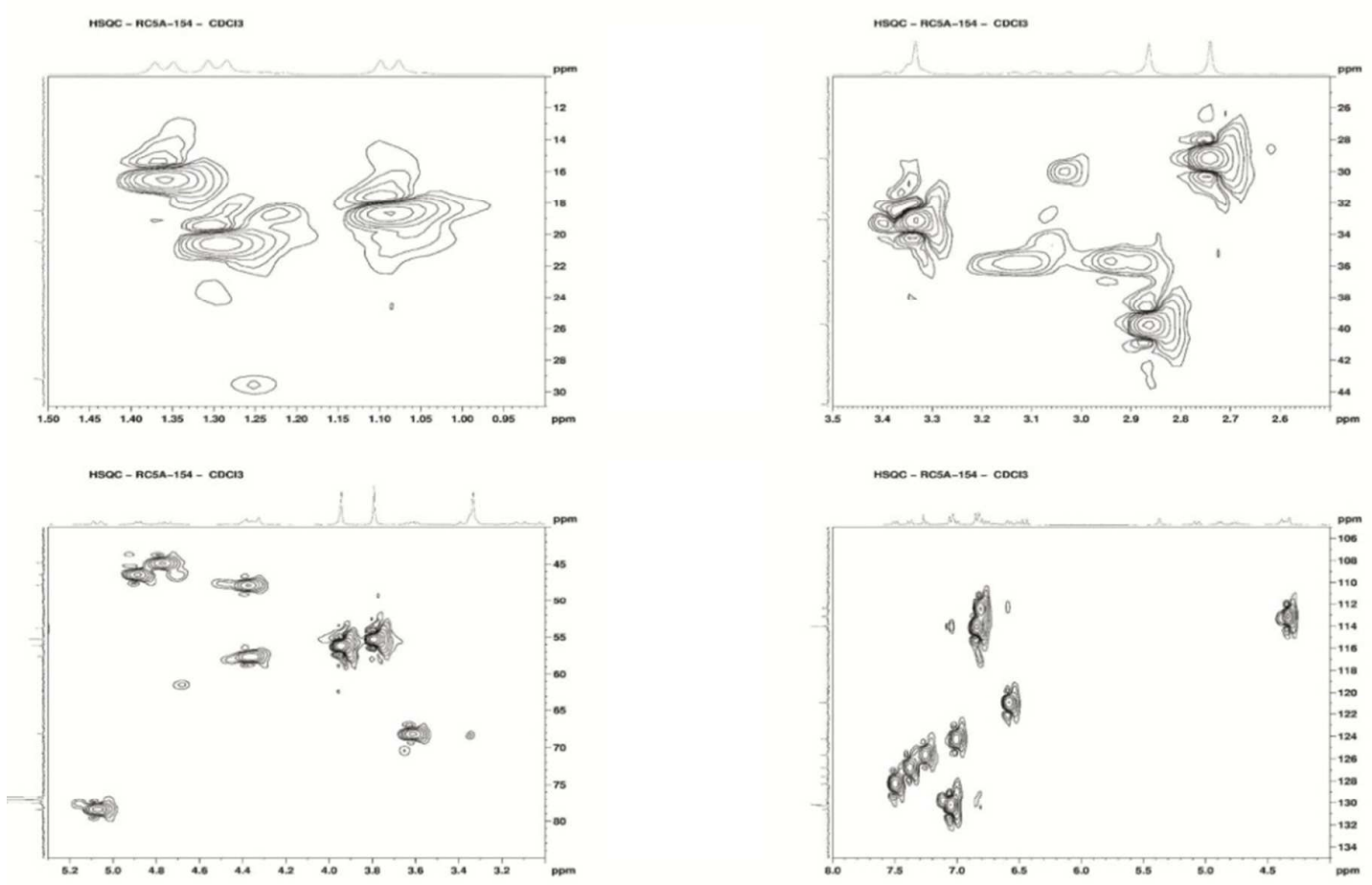

Fig. S 2 - HSQC NMR (300/75 $\mathrm{MHz}, \mathrm{CDCl}_{3}$ ) spectrum expansions of 6-O-methylbouvardin. 


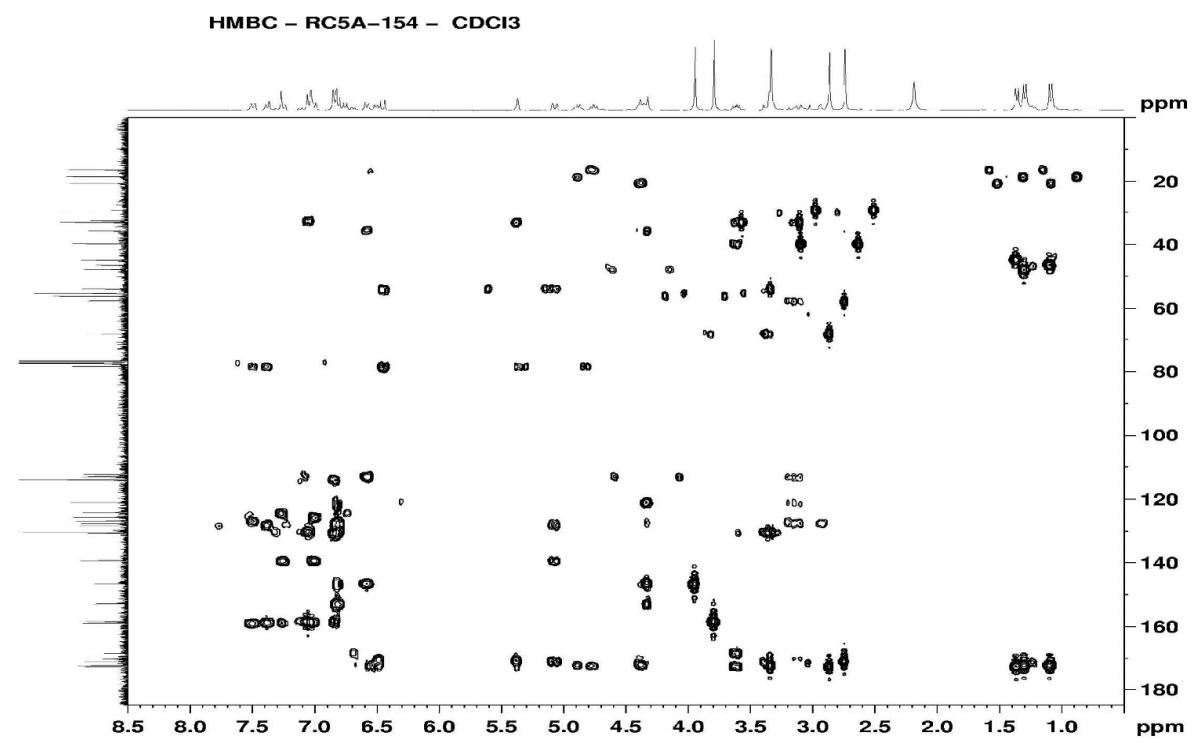

Fig. $\mathrm{S} 3$ - HMBC NMR (300/75 MHz, $\mathrm{CDCl}_{3}$ ) spectrum of 6-O-methylbouvardin.
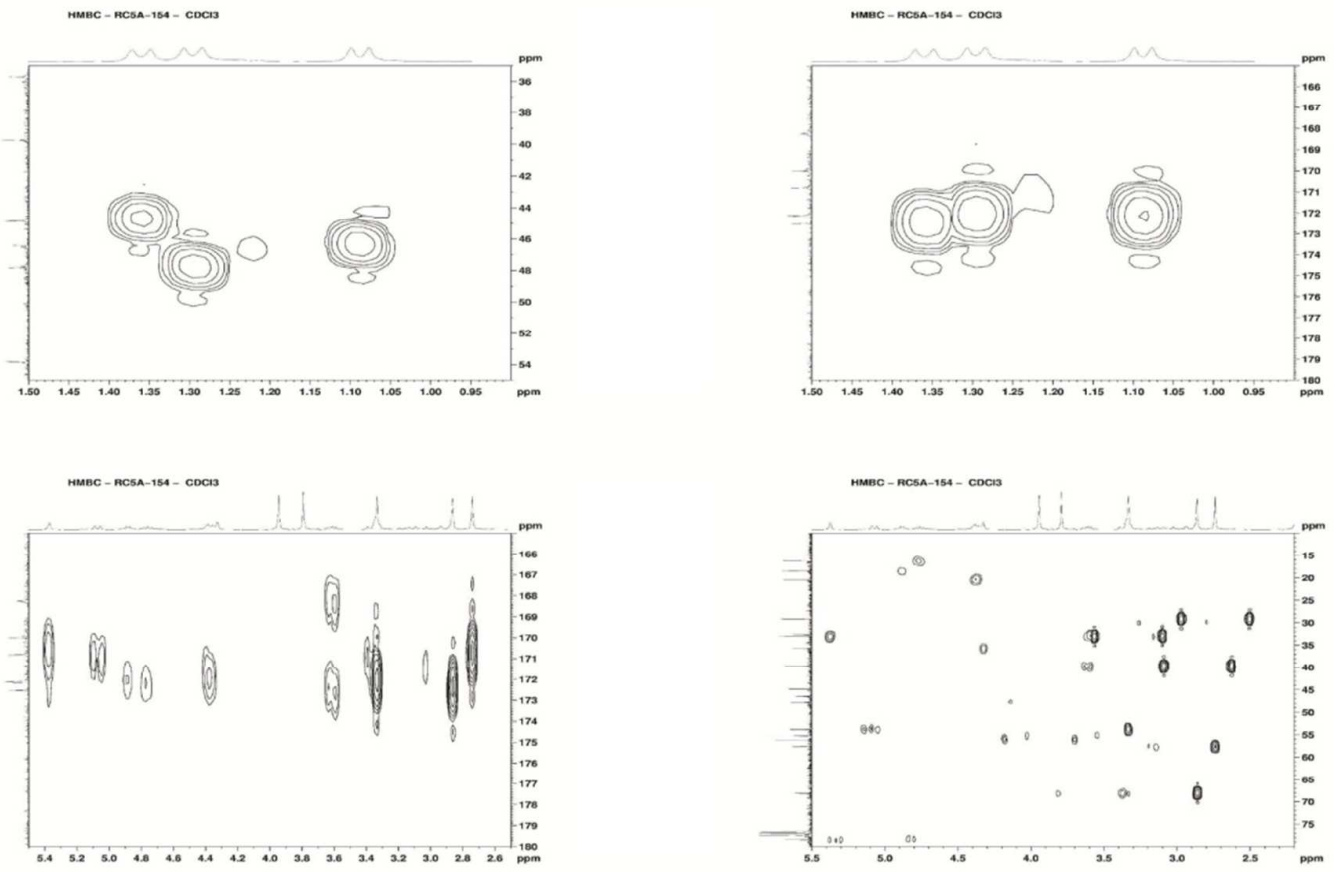

Fig. S 4 - $\mathrm{HMBC}$ NMR (300/75 $\left.\mathrm{MHz}, \mathrm{CDCl}_{3}\right)$ spectrum expansions of 6-O-methylbouvardin. 

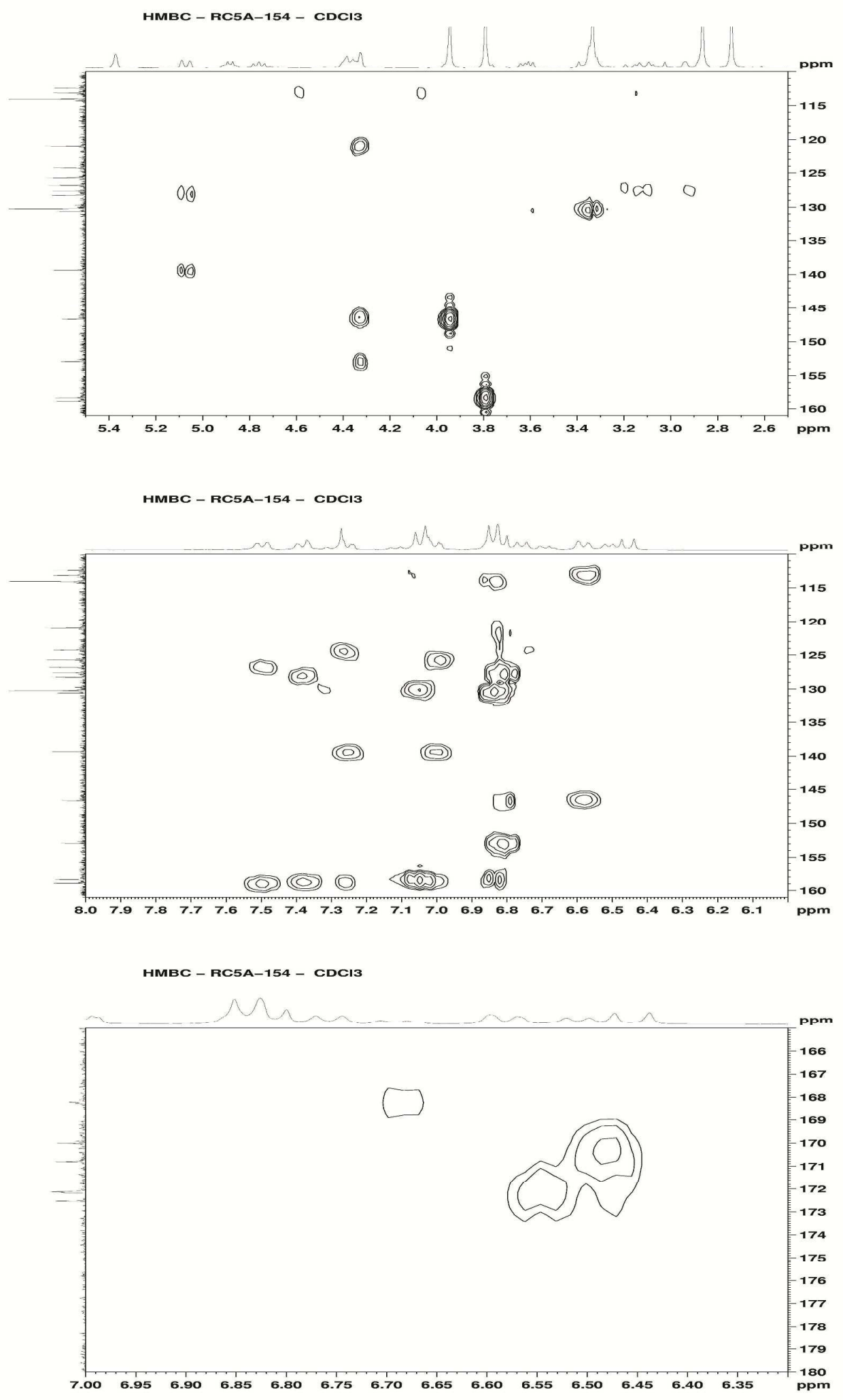

Fig. S 5 - $\mathrm{HMBC}$ NMR (300/75 MHz, $\left.\mathrm{CDCl}_{3}\right)$ spectrum expansions of 6-O-methylbouvardin. 


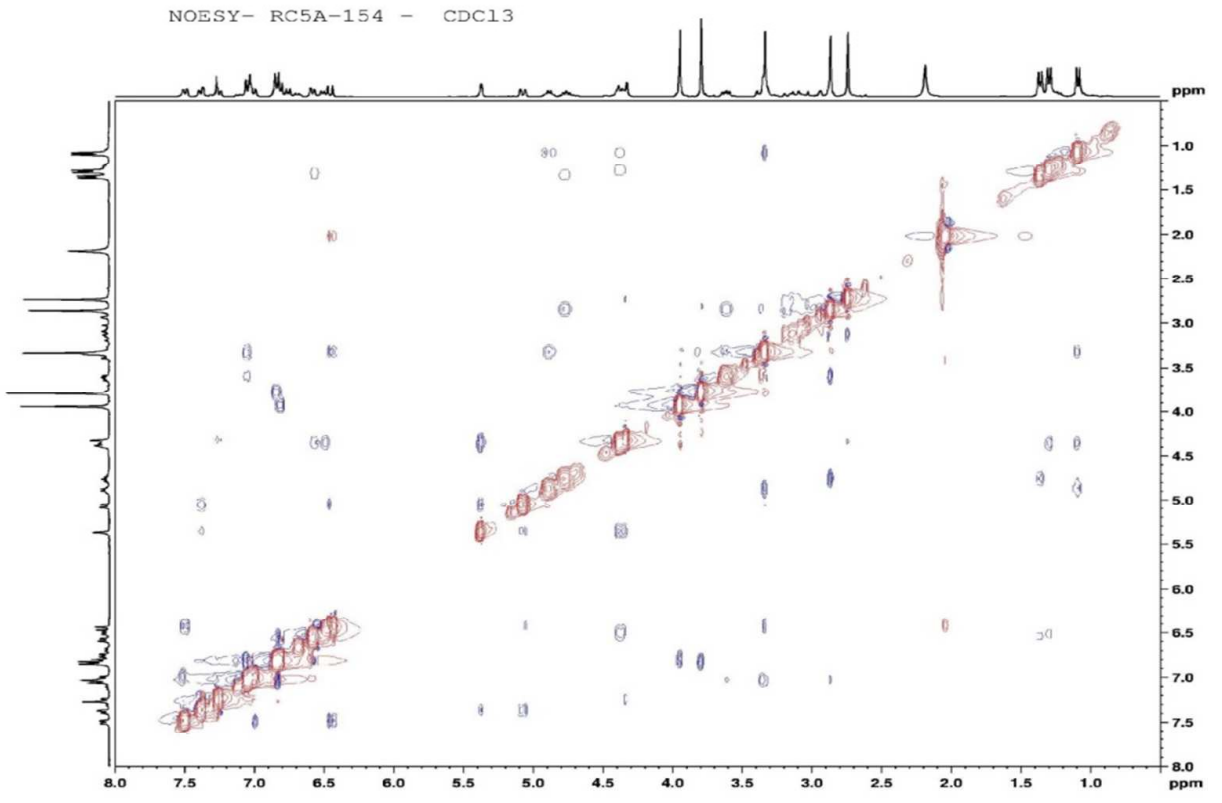

Fig. S 6 - NOESY NMR (300 MHz, CDC13) spectrum of 6-O-methylbouvardin.

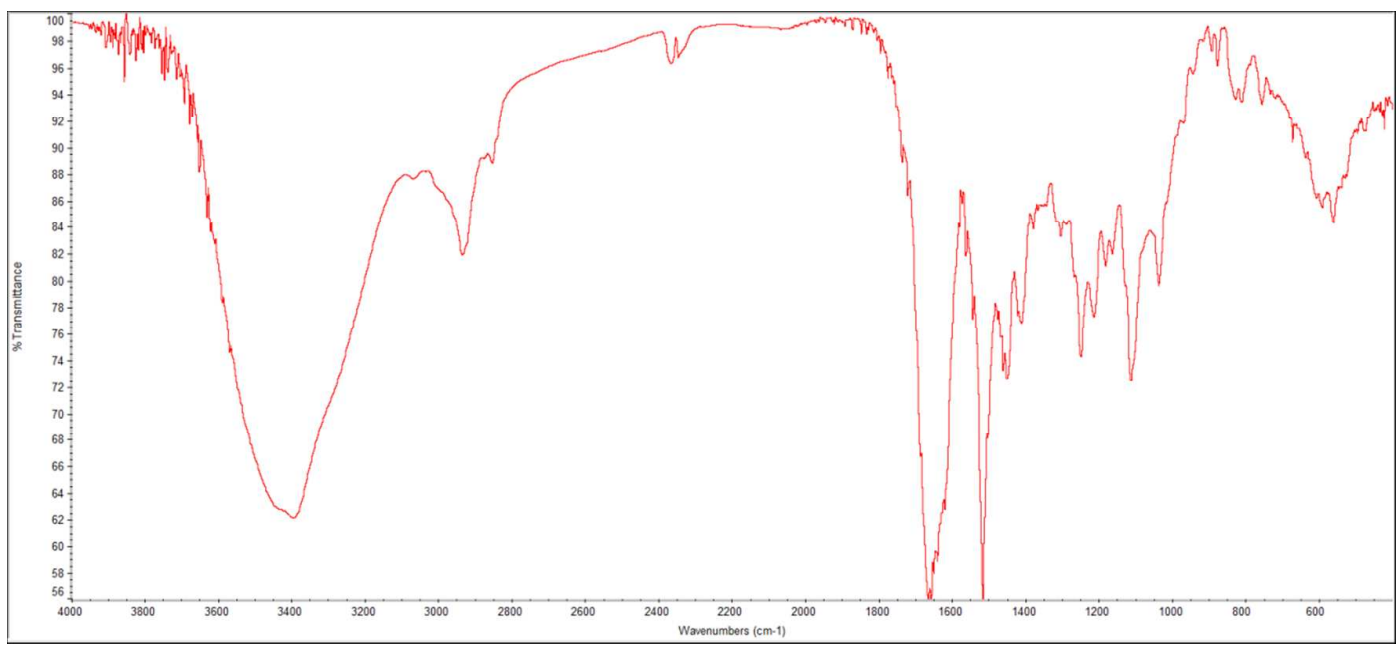

Fig. S 7 - IR spectrum of 6-O-methylbouvardin ( $\mathrm{KBr}$ pellet method). 


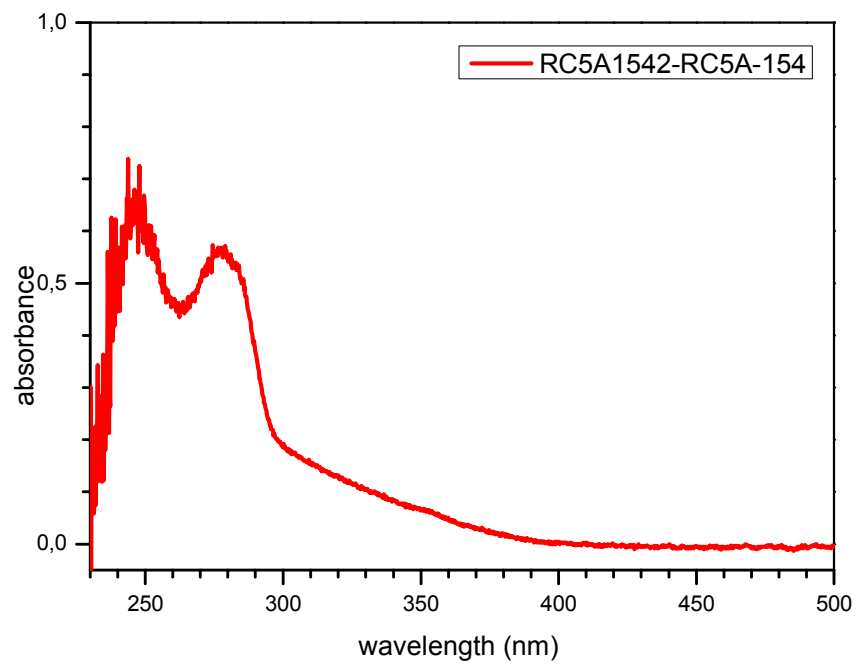

Fig. S 8 - UV spectrum of 6-O-methylbouvardin (MeOH).

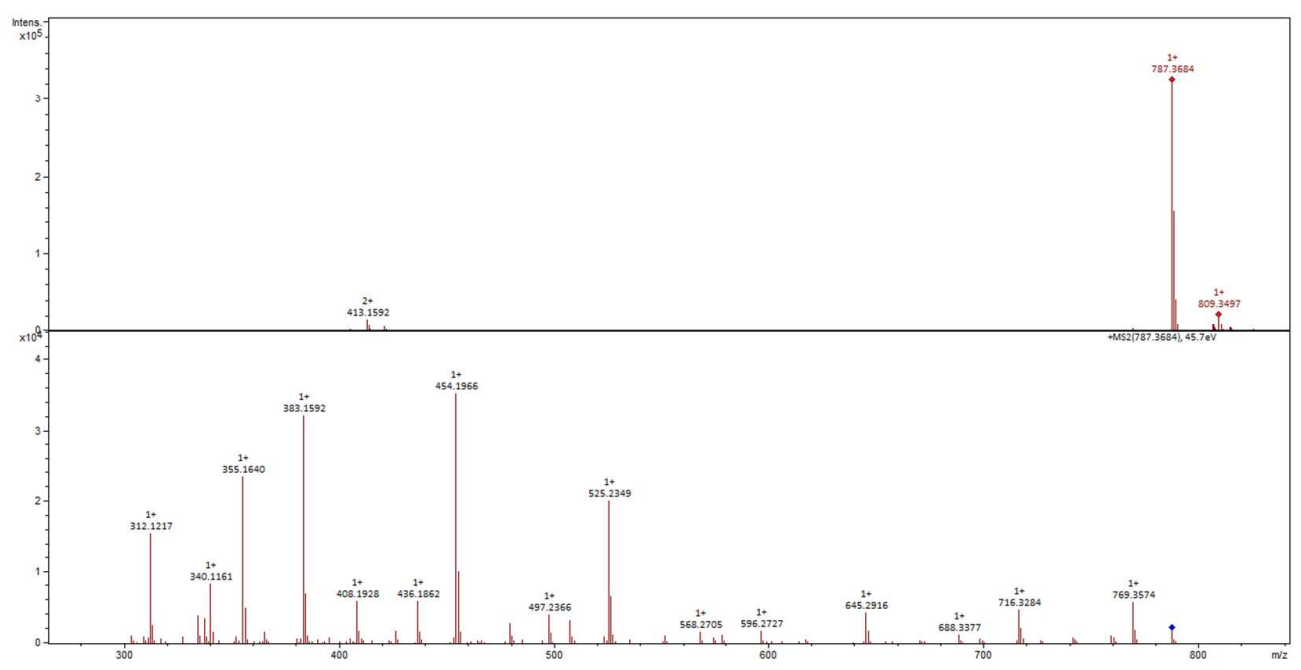

Fig. S 9- HR-ESI-MS/MS spectrum of 6-O-methylbouvardin. 


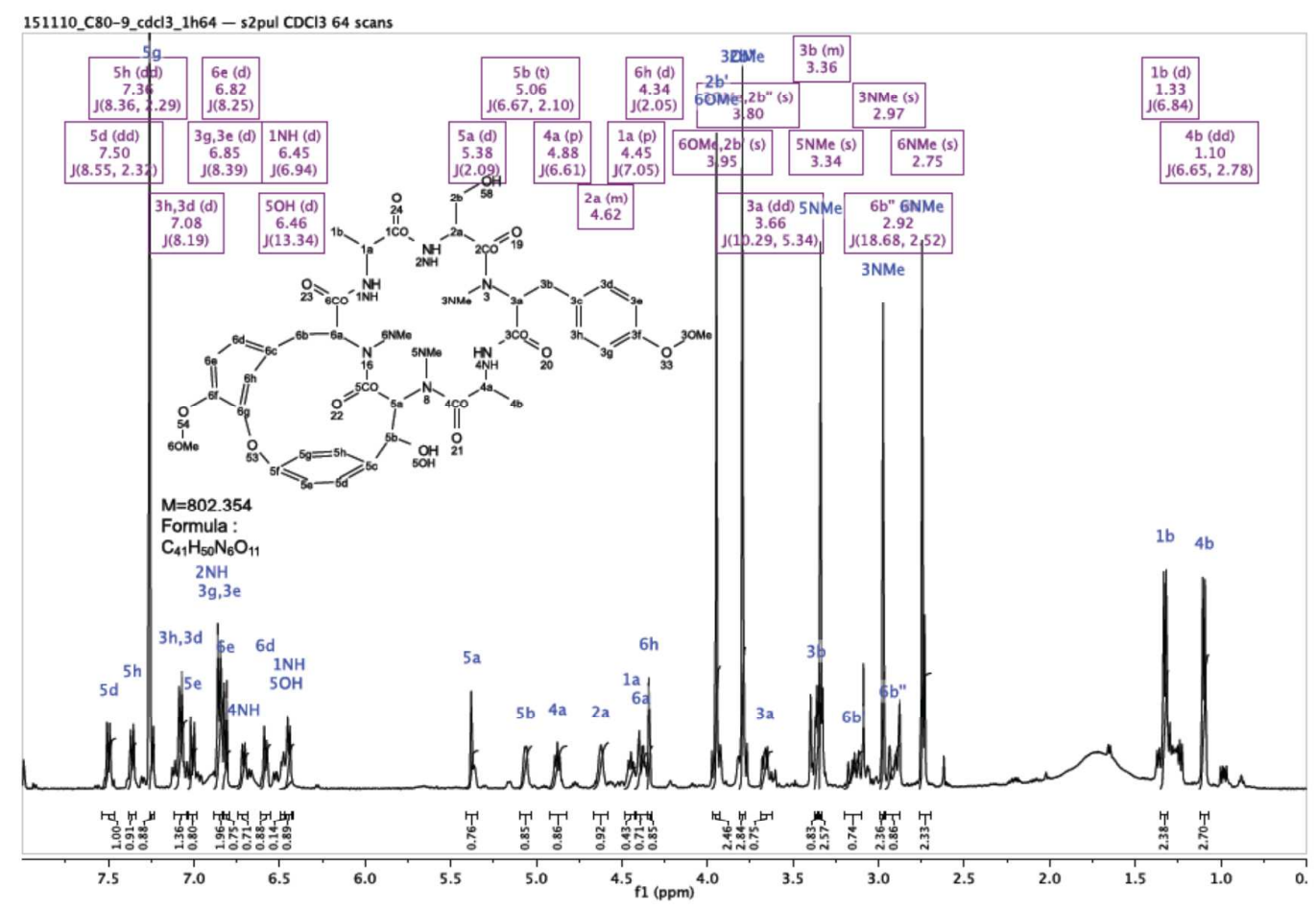

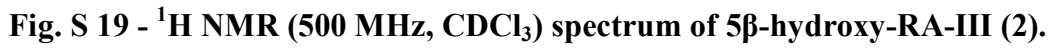

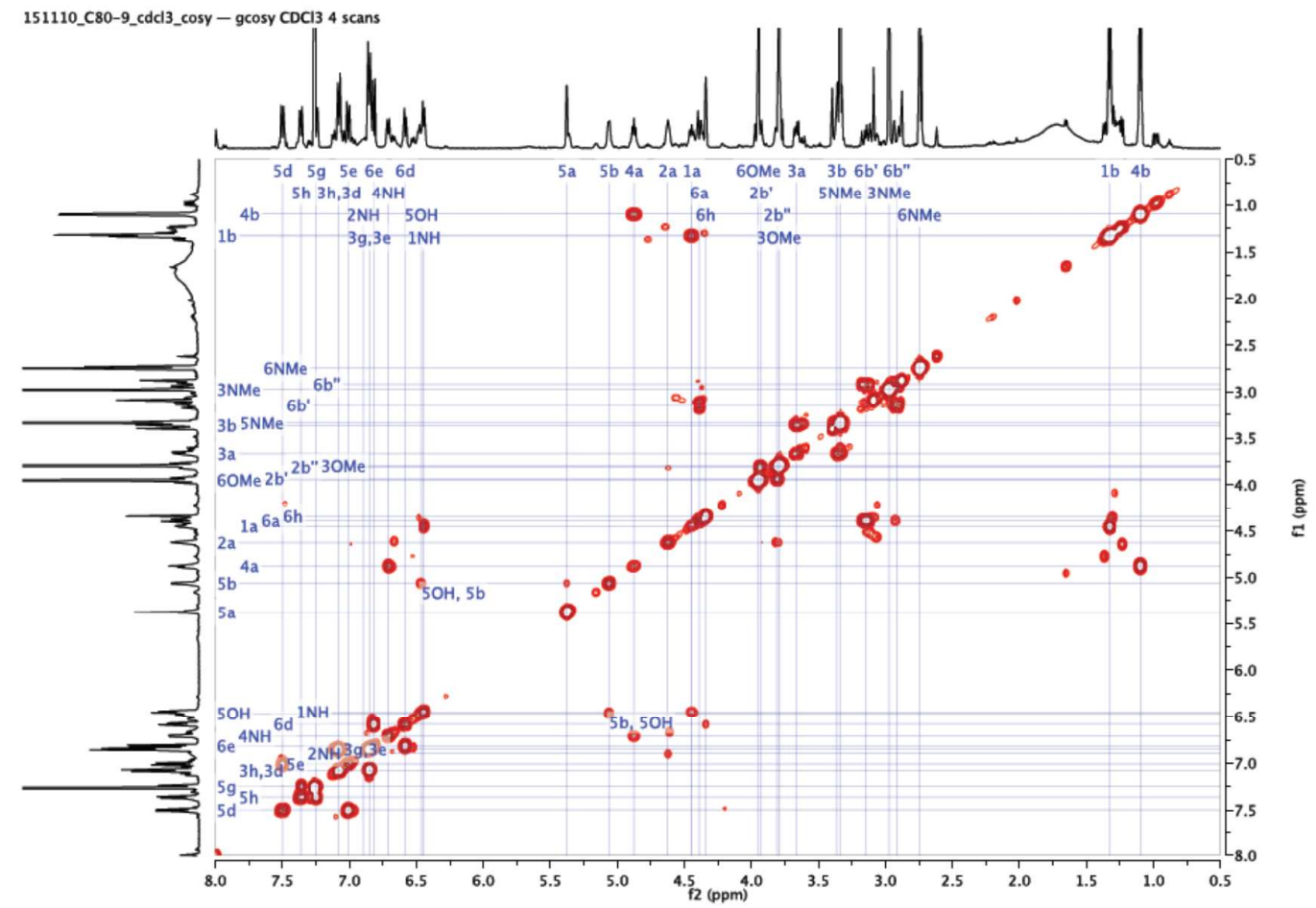

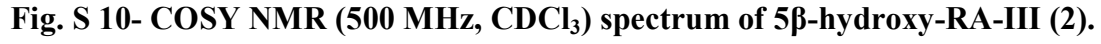




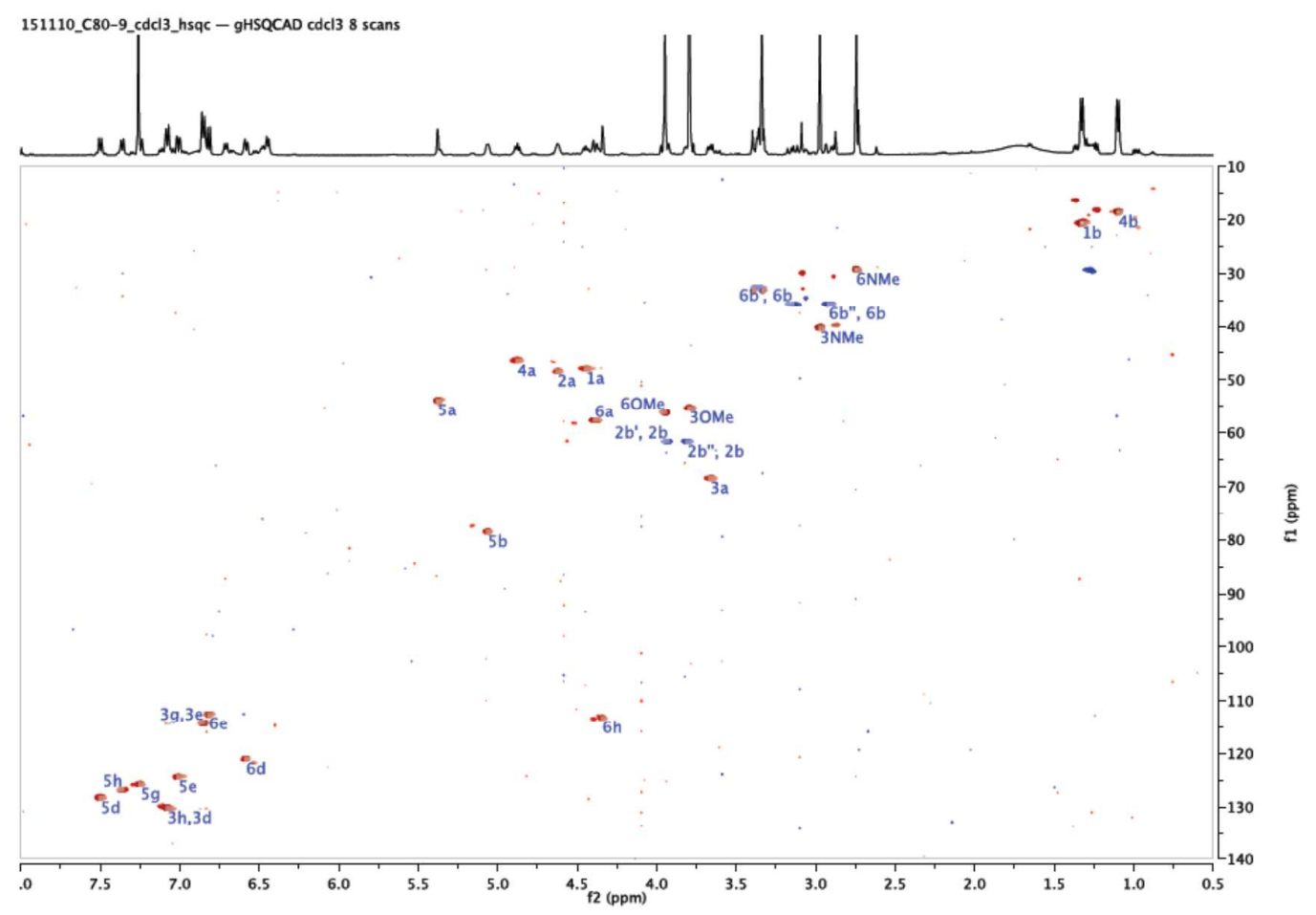

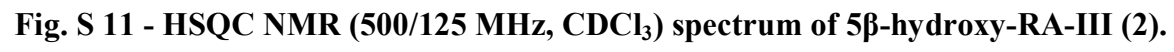

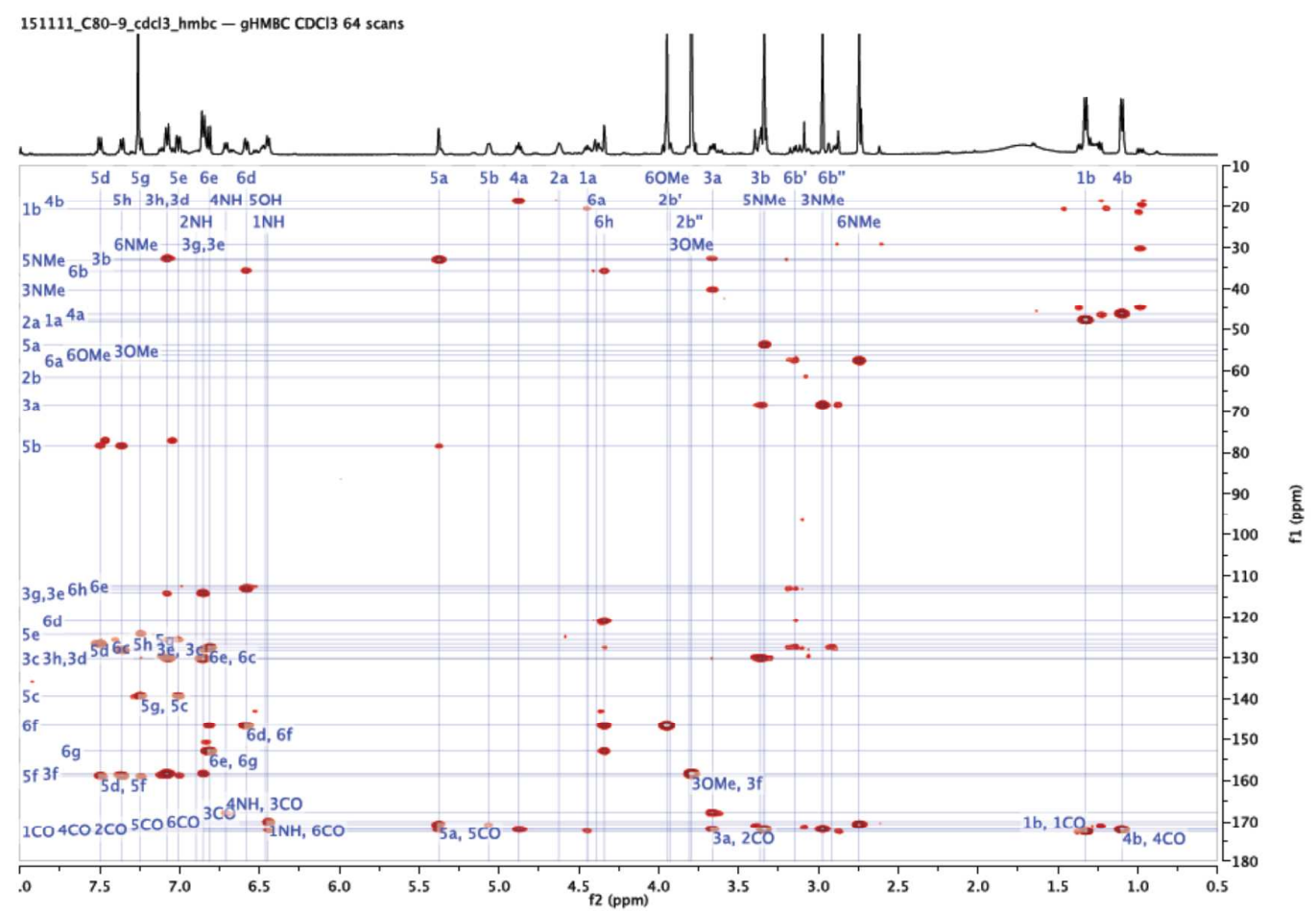

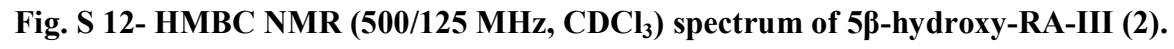




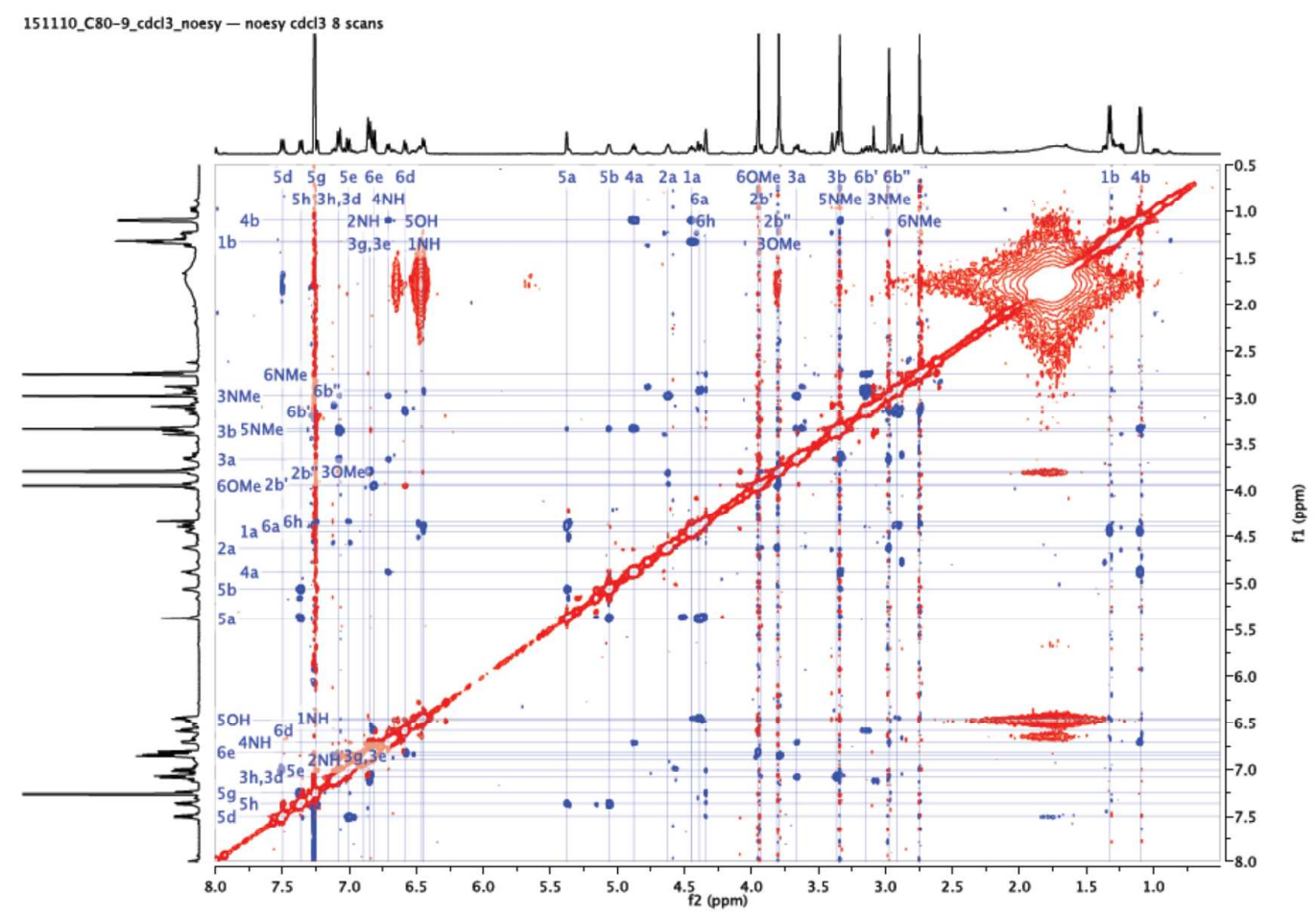

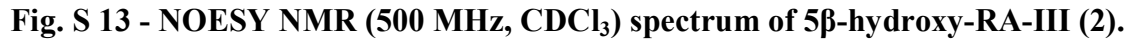

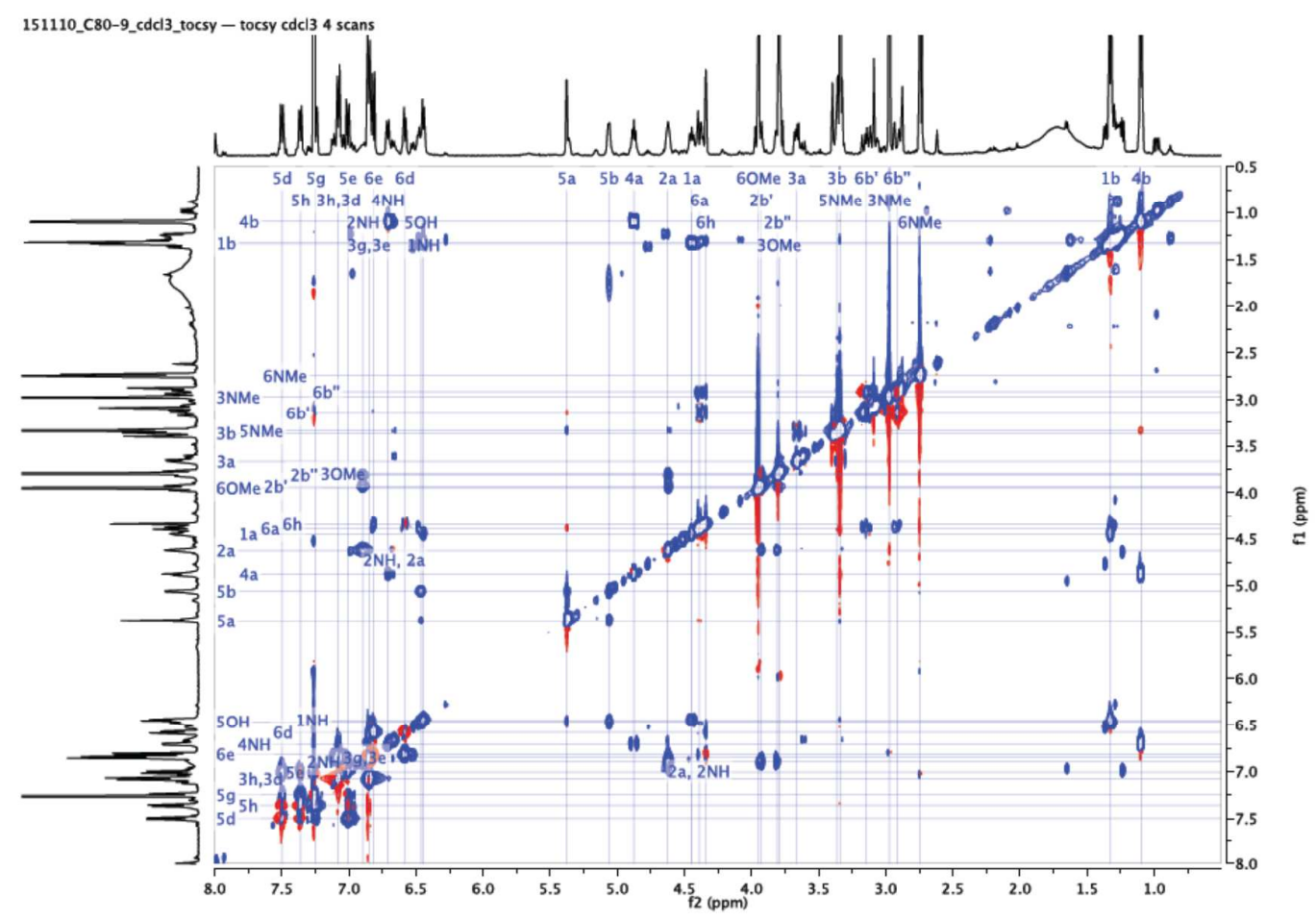

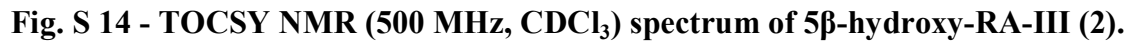




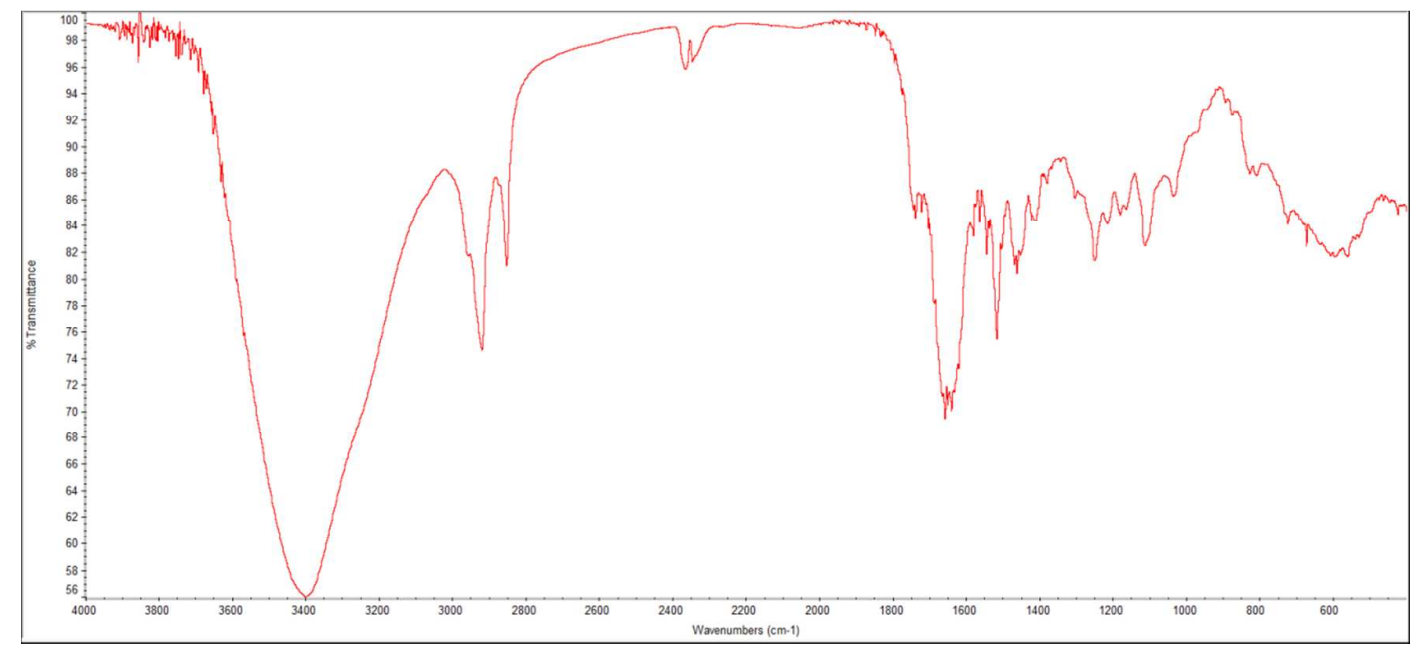

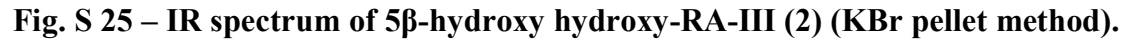

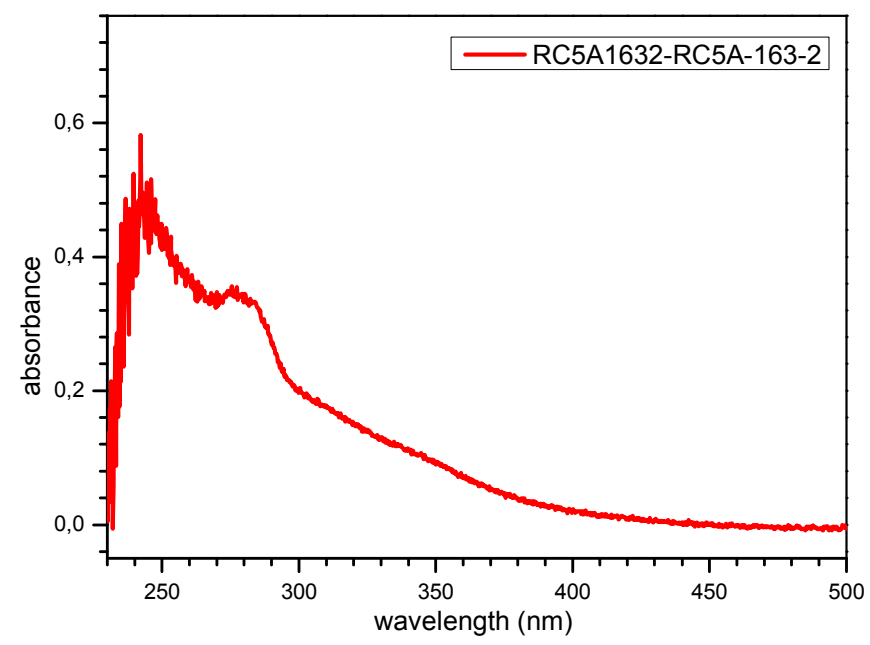

Fig. S 15 - UV spectrum of 5ß-hydroxy hydroxy-RA-III (2) (MeOH). 


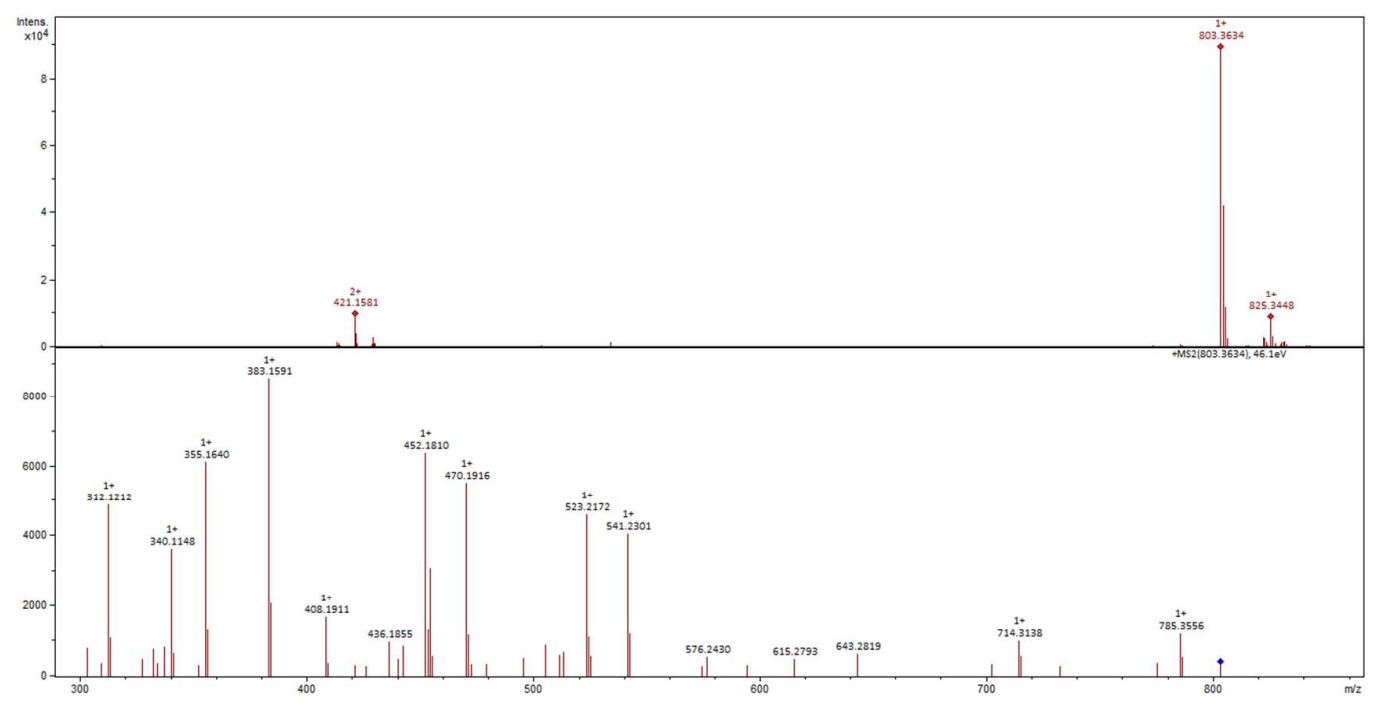

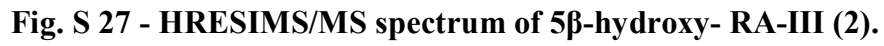

\section{References}

(1) Paizs, B.; Suhai, S. Mass Spectrom. Rev. 2005, 24, 508-548.

(2) Harrison, A. G.; Young, A. B.; Bleiholder, C.; Suhai, S.; Paizs, B. J. Am. Chem. Soc. 2006, 128, 10364-10365.

(3) Chawner, R.; Gaskell, S. J.; Eyers, C. E. Rapid Commun. Mass Spectrom. 2012, 26, 205-206.

(4) Yagüe, J.; Paradela, A.; Ramos, M.; Ogueta, S.; Marina, A.; Barahona, F.; López de Castro, J. A.; Vazquez, J. Anal. Chem. 2003, 75, 1524-1535.

(5) Ngoka, L. C. M.; Gross, M. L. J. Amer. Soc. Mass Spectrom. 1999, 10, 360-363.

(6) Fan, J. T.; Chen, Y. S.; Xu, W. Y.; Du, L.; Zeng, G. Z.; Zhang, Y. M.; Su, J.; Li, Y.; Tan, N. H. Tetrahedron Lett. 2010, 51, 6810-6813.

(7) Bhushan, R.; Brückner, H. Amino acids 2004, 27, 231-247.

(8) Monks, A.; Scudiero, D.; Skehan, P.; Shoemaker, R.; Paull, K.; Vistica, D.; Hose, C.; Langley, J.; Cronise, P.; Vaigro-Wolff, A. J. Natl. Cancer Inst. 1991, 83, 757-766.

(9) Houghton, P.; Fang, R.; Techatanawat, I.; Steventon, G.; Hylands, P. J.; Lee, C. Methods 2007, 42, 377-387. 